\title{
EFFICACY OF WASHING AND POSTHARVEST TREATMENTS ON SHELF LIFE AND QUALITY OF OYSTER MUSHROOM
}

\author{
P. K. Das, M. K. Hassan and N. Akhther \\ Department of Horticulture, Bangladesh Agricultural University \\ Mymensingh-2202, Bangladesh
}

\begin{abstract}
An experiment was conducted to study the efficacy of washing (control and 5\% hydrogen peroxide) and postharvest treatments (control, hot water treatment, wrapping with unperforated and perforated plastic bags, wrapping with brown paper bag and wrapping with aluminum foil) on shelf life and quality of oyster mushroom. Postharvest treatments caused significant effects to influence weight loss, dry matter and protein contents, disease incidence and shelf life of mushroom. At the $7^{\text {th }}$ day of storage, the highest weight loss $(98.08 \%)$ was recorded in the untreated mushrooms, whereas the lowest weight loss $(33.62 \%)$ was observed in mushrooms wrapped in unperforated plastic bag. Protein content was observed to be higher $(28.98 \%)$ in mushrooms wrapped with unperforated plastic bag followed by perforated plastic bag $(25.00 \%)$ at the $5^{\text {th }}$ day of storage. Protein content declined dramatically in mushrooms held at ambient conditions. The lowest protein content $(2.97 \%)$ was recorded in the untreated mushrooms at the $7^{\text {th }}$ day of storage. Unwashed mushrooms held at ambient temperature had the highest incidence of disease. The longest shelf life of 6 days was recorded in mushrooms wrapped in unperforated plastic bag, whereas the shortest shelf life (3 days) was found in the untreated mushrooms.
\end{abstract}

Key Words: Oyster mushroom Pleurotus florida, Shelf life, Washing, Modified atmosphere

\section{INTRODUCTION}

Mushroom is a fleshy, spore-bearing fruiting body of a fungus grown above-ground on its food sources. Edible mushroom is one of the most popular food items all over the world. Mushroom contains 20-35\% protein, which is higher than those of many vegetables and fruits (Pathak et al., 1997). Mushroom production and processing. It also contains appreciable amounts of vitamin C and B complex, potassium, phosphorus and sodium (Pathak et al., 1997). Mushrooms have high water content (85-95\%), which is lost rapidly by evaporation and transpiration. The rate of water loss depends on mushroom structures, and relative humidity, temperature, air movement and atmospheric pressure of the storage environment. The major limitations in mushroom marketing include wilting and shriveling due to rapid water loss, which render them unfit for marketing and consumption. Washing of mushroom is useful to extend shelf life. Different types of washing treatments have been examined in reducing postharvest spoilage of mushrooms. 
Types of washing techniques include $0.5 \%$ calcium chloride and $0.5 \%$ citric acid (Jayathunge and Illeperuma, 2001 \& 2005), combination wash with $50 \mathrm{ppm}$ chlorine dioxide, $0.1 \%$ sodium erythrobate and $0.05 \%$ calcium chloride (Guthire and Beelman, 1989), and $0.5-1.5 \%$ potassium metabisulphite (Gothandapani et al., 1997). The storage of mushrooms in modified atmosphere packaging (MAP) is effective in reducing moisture loss. The use of MAP is an inexpensive tool in storing perishables. MAP regulates gaseous exchange, reduces weight loss and spoilage, and maintains quality of mushrooms during postharvest handling. Maximum shipping period of oyster mushroom appeared to be 21 days considering additional 5-day marketing period at low temperature of $7^{\circ} \mathrm{C}$ while stored in tray type packages (YounMoon et al., 2004). Once the mushroom matures, the degradation process starts, and the mushroom becomes inedible. Development of brown colour is the first sign of deterioration and is a major factor contributing to quality losses. The present study was therefore undertaken to examine suitability of washing and modified atmosphere packaging to extend shelf life and maintain quality of oyster mushroom.

\section{MATERIALS AND METHODS}

The experiment was carried out at the laboratory of the Department of Horticulture, Bangladesh Agricultural University, Mymensingh. The experiment consisted of two factors, namely washing (no-washing and washing with $5 \% \quad \mathrm{H}_{2} \mathrm{O}_{2}$ ) and modified atmosphere packaging (unwrap control, hot water treatment @ $40 \pm 2^{\circ} \mathrm{C}$ for 40 seconds, wrapping with plastic bags with or without perforations, brown paper and aluminum foil), and the experiment was laid out in a completely randomized design with three replications of 12 fruiting bodies. The experimental mushrooms were obtained from National Mushroom Development and Extension Center, Savar, Dhaka, Bangladesh. Parameters investigated were freshness, colour, dry matter content, weight loss, total protein, disease incidence and shelf life. Freshness and colour of mushrooms were determined objectively using numerical rating scales. For determination of weight loss, initially the fruiting bodies of each replication of each treatment were weighed. Weight loss was calculated using the following formula, weight loss $(\%)=($ Initial weight - Final weight)/Initial weight $\times 100$. For dry matter estimation, firstly moisture content was determined. For this, $5 \mathrm{~g}$ of fruiting bodies was weighed in a Petri dish from each replication of each treatment. The Petri dish was placed in an electric oven at $80^{\circ} \mathrm{C}$ for 72 hrs until a constant weight attained. Moisture content was calculated using the formula, moisture content $(\%)=($ Moist weight - Dry weight $) /$ Moist weight $\times 100$. Then the dry matter content was found out using the formula, dry matter $(\%)=(100-\%$ moisture content). Total protein content was estimated using the modified micro-Kjeldahl method (AOAC, 1980). Protein estimation was based on estimating nitrogen content. Total protein was calculated by multiplying nitrogen content by 6.25 . This is expressed as crude protein since the non-protein nitrogen was also taken into consideration in the present method of protein determination. Disease incidence was calculated by the formula, disease incidence $(\%)=($ Number of infected fruiting body/Total number of fruiting body $) \times 100$.

Shelf life was determined by counting the number of days until which optimum 
marketing and eating qualities were retained. Data were statistically analyzed and analysis of variance for the parameters was accomplished by $\mathrm{F}$ variance test. The mean separation was done by LSD (Gomez and Gomez, 1984).

\section{RESULTS AND DISCUSSION}

\section{Freshness}

Freshness is one of the important qualities of edible mushrooms. The tissues of mushroom fruiting bodies become softer and get spoiled due to water loss. Washing caused significant effect in retaining freshness. Freshness of mushroom at the $3^{\text {rd }}$ day of storage was fair (2.3), which changed to unacceptable stage (4.4) at the $7^{\text {th }}$ day of storage in the unwashed mushrooms. On the other hand, the washed mushrooms had better freshness scores (Table 1). Modified atmosphere (MA) packaging exerted significant effects on freshness changes during storage. Freshness deteriorated with the duration of storage in all MA treatments at varying rates. Freshness score was 2.8 in the untreated mushroom, whereas the mushrooms wrapped in unperfoaretd plastic bags had freshness score 1.5 at the $3^{\text {rd }}$ day of storage (Table 2). The present result was at par with the findings of Choi and Kim (2003) who reported that film packaging prevented the deterioration of mushroom freshness and texture during storage. The degradation of freshness over time would probably due to the increase in transpiration, dehydration, respiration and disease attack.

Table 1. Effects of washing on freshness and colour of oyster mushroom during storage

\begin{tabular}{l|c|c|c|c|c|c}
\hline \multirow{2}{*}{ Washing } & \multicolumn{3}{|c|}{$\begin{array}{c}\text { Freshness at different days after } \\
\text { storage }\end{array}$} & \multicolumn{3}{c}{$\begin{array}{c}\text { Colourb at different days after } \\
\text { storage }\end{array}$} \\
\cline { 2 - 7 } & 3 & 5 & 7 & 3 & 5 & 7 \\
\hline Control (unwashed) & 2.3 & 3.3 & 4.4 & 2.3 & 3.2 & 4.5 \\
Washing with $\mathrm{H}_{2} \mathrm{O}_{2}$ & 2.0 & 3.1 & 4.1 & 1.9 & 3.0 & 4.1 \\
Level of significance & $* *$ & $* *$ & $* *$ & $* *$ & $* *$ & $* *$ \\
\hline LSD $_{(0.05)}$ & 0.15 & 0.11 & 0.13 & 0.22 & 0.10 & 0.24 \\
\hline LSD $_{(0.01)}$ & 0.26 & 0.18 & 0.28 & 0.37 & 0.18 & 0.35 \\
\hline
\end{tabular}

** = significant at $1 \%$ level of probability. ${ }^{a}=$ Freshness scale $(1-1.4=$ excellent, $1.5-2.4=$ good, 2.5 $3.4=$ fair, $3.5-4.4=$ poor, $4.5-5.0=$ unacceptable $) ; \mathrm{b}=$ Colour scale $(1-1.4=$ white, $1.5-2.4=$ onequarter brown, 2.5-3.4 = half-brown, 3.5-4.4 = three-quarter brown, 4.5-5.4 = full brown, 5.5-6.0 $=$ black $/$ rotten)

\section{Colour}

Gradual change in colour of mushroom from white to black occurs with the duration of storage. Washing showed significant variation in the retention of colour during storage. The colour score at the $3^{\text {rd }}$ day of storage was 2.3 (one-quarter brown), which increased to nearly 4.5 (unacceptable) at the $7^{\text {th }}$ day of storage in unwashed mushrooms. On the other hand, the washed mushrooms at the $3^{\text {rd }}$ and $7^{\text {th }}$ days of storage had colour scores of 1.9 
(one-quarter brown) and 4.1 (three-quarter brown), respectively (Table 1). Postharvest treatments resulted in significant effects in colour changes during storage. The deterioration of mushroom colour was observed in all treatments at varying rates. At the $3^{\text {rd }}$ day of storage, the mushrooms of control (2.8), aluminum foil (2.4) and brown paper (2.3) were found half-brown (unacceptable), whereas the mushrooms wrapped in unperforated (1.6) and perforated plastic bags (1.9), and those treated with hot water (1.9) remained acceptable in terms of colour. Combined wash with chlorine dioxide, sodium erythorbate and calcium chloride was found effective to reduce the bacterial population and caused less colour deterioration during storage of mushroom (Guthrie and Beelman, 1989). Rajarathnam et al. (1983) observed an increase in activities of o-diphenol oxidase and proteases, and a fall in total phenols and an increase in free amino acids, which might have resulted in the increased discoloration of mushroom with the progress in storage duration.

Table 2. Effects of modified atmosphere packaging on freshness and colour of oyster mushroom during storage

\begin{tabular}{l|c|c|c|c|c|c}
\hline \multicolumn{1}{c}{$\begin{array}{c}\text { Modified atmosphere packaging } \\
\text { (MAP) }\end{array}$} & \multicolumn{3}{c|}{$\begin{array}{c}\text { Freshess a different days } \\
\text { after storage }\end{array}$} & \multicolumn{3}{c}{$\begin{array}{c}\text { Colour }{ }^{\mathrm{b}} \text { at different days } \\
\text { after storage }\end{array}$} \\
\cline { 2 - 7 } & 3 & 5 & 7 & 3 & 5 & 7 \\
\hline Control (ambient condition) & 2.8 & 4.4 & 4.9 & 2.8 & 4.4 & 5.2 \\
Hot water treatment $\left(40 \pm 2^{\circ} \mathrm{C}\right)$ & 2.2 & 3.2 & 4.3 & 1.9 & 2.5 & 4.3 \\
Wrapping in unperforated plastic bag & 1.5 & 2.1 & 3.2 & 1.6 & 2.1 & 3.3 \\
Wrapping in perforated plastic bag & 1.9 & 2.7 & 4.3 & 1.9 & 2.5 & 4.3 \\
Wrapping in brown paper bag & 2.3 & 3.5 & 4.3 & 2.7 & 3.2 & 4.3 \\
Wrapping in aluminum foil & 2.4 & 3.4 & 4.5 & 2.4 & 3.5 & 4.5 \\
\hline Level of significance & $* *$ & $* *$ & $* *$ & $* *$ & $* *$ & $* *$ \\
\hline LSD $_{(0.05)}$ & 0.16 & 0.19 & 0.19 & 0.19 & 0.16 & 0.22 \\
\hline LSD $_{(0.01)}$ & 0.20 & 0.25 & 0.26 & 0.26 & 0.28 & 0.29 \\
\hline
\end{tabular}

** = significant at $1 \%$ level of probability. ${ }^{a}=$ Freshness scale $(1-1.4=$ excellent, $1.5-2.4=$ good, 2.5 $3.4=$ fair, $3.5-4.4=$ poor, $4.5-5.0=$ unacceptable $) ; \mathrm{b}=$ Colour scale $(1-1.4=$ white, $1.5-2.4=$ onequarter brown, 2.5-3.4 = half-brown, 3.5-4.4 = three-quarter brown, 4.5-5.4 = full brown, 5.5-6.0 =black $/$ rotten)

\section{Total weight loss}

Significant variation was observed between washed and unwashed mushrooms in respect of total weight loss. At the $3^{\text {rd }}$ day of storage, total weight loss was $38.89 \%$ in unwashed mushrooms which increased to $62.04 \%$ at the $7^{\text {th }}$ day of storage (Table 4 ). Modified atmosphere packaging exhibited pronounced effects in reducing total weight loss of mushroom during storage. At the $7^{\text {th }}$ day of storage, total weight loss was found to be the maximum $(89.08 \%)$ in the unwrapped mushrooms, whereas the minimum $(33.62 \%)$ weight loss was observed in mushrooms held in unperforated plastic bag (Table 5). The 
combined effects of washing and modified atmosphere packaging were significant in terms of weight loss of mushroom fruiting bodies during storage (Table 6).

Table 3. Combined effects of washing and modified atmosphere packaging freshness and colour of oyster mushroom during storage

\begin{tabular}{|c|c|c|c|c|c|c|c|}
\hline \multirow{2}{*}{\multicolumn{2}{|c|}{ Washing $\times$ MAP }} & \multicolumn{3}{|c|}{$\begin{array}{c}\text { Freshness a at different days after } \\
\text { storage }\end{array}$} & \multicolumn{3}{|c|}{$\begin{array}{c}\text { Colourb at different days after } \\
\text { storage }\end{array}$} \\
\hline & & 3 & 5 & 7 & 3 & 5 & 7 \\
\hline \multirow{6}{*}{$\begin{array}{l}\text { Control } \\
\text { (non-washed) }\end{array}$} & $\mathrm{T}_{1}$ & 2.9 & 4.6 & 5.0 & 2.9 & 4.6 & 5.3 \\
\hline & $\mathrm{T}_{2}$ & 2.3 & 3.3 & 4.4 & 2.4 & 3.3 & 4.4 \\
\hline & $\mathrm{T}_{3}$ & 1.7 & 2.2 & 3.3 & 1.7 & 2.2 & 3.4 \\
\hline & $\mathrm{T}_{4}$ & 2.0 & 2.7 & 4.4 & 2.0 & 2.6 & 4.4 \\
\hline & $\mathrm{T}_{5}$ & 2.4 & 3.6 & 4.5 & 2.0 & 2.8 & 4.4 \\
\hline & $\mathrm{T}_{6}$ & 2.5 & 3.7 & 4.8 & 2.5 & 3.7 & 4.8 \\
\hline \multirow{6}{*}{$\begin{array}{l}\text { Washed with } \\
\mathrm{H}_{2} \mathrm{O}_{2}\end{array}$} & $\mathrm{~T}_{1}$ & 2.7 & 4.2 & 4.8 & 2.7 & 4.2 & 5.0 \\
\hline & $\mathrm{T}_{2}$ & 2.1 & 3.1 & 4.2 & 2.2 & 3.0 & 4.2 \\
\hline & $\mathrm{T}_{3}$ & 1.4 & 1.9 & 3.0 & 1.4 & 2.0 & 3.1 \\
\hline & $\mathrm{T}_{4}$ & 1.9 & 2.7 & 4.1 & 1.7 & 2.4 & 4.1 \\
\hline & $\mathrm{T}_{5}$ & 2.2 & 3.3 & 4.1 & 1.7 & 2.3 & 4.2 \\
\hline & $\mathrm{T}_{6}$ & 2.3 & 3.2 & 4.2 & 2.2 & 3.4 & 4.2 \\
\hline \multicolumn{2}{|c|}{ Level of significance } & $* *$ & $* *$ & $* *$ & $* *$ & $* *$ & $* *$ \\
\hline \multicolumn{2}{|l|}{$\operatorname{LSD}_{(0.05)}$} & 0.23 & 0.26 & 0.27 & 0.27 & 0.23 & 0.31 \\
\hline \multicolumn{2}{|l|}{$\operatorname{LSD}_{(0.01)}$} & 0.31 & 0.35 & 0.37 & 0.36 & 0.31 & 0.42 \\
\hline
\end{tabular}

$\mathrm{T}_{1}$ : Control (ambient condition), $\mathrm{T}_{2}$ : Hot water treatment $\left(40 \pm 2{ }^{\circ} \mathrm{C}\right), \mathrm{T}_{3}$ : Wrapping in unperforated plastic bag, $\mathrm{T}_{4}$ : Wrapping in perforated plastic bag, $\mathrm{T}_{5}$ : Wrapping in brown paper bag, $\mathrm{T}_{6}$ : Wrapping in aluminum foil, $* *=$ Significant at $1 \%$ level of probability. ${ }^{a}=$ Freshness scale $(1-1.4=$ excellent, $1.5-2.4=$ good, $2.5-3.4=$ fair, 3.5-4.4 = poor, 4.5-5.0 = unacceptable); $\mathrm{b}=$ Colour scale $(1-1.4$ $=$ white, $1.5-2.4=$ one-quarter brown, $2.5-3.4=$ half - brown, 3.5-4.4 $=$ three-quarter brown, $4.5-5.4=$ full brown, 5.5-6.0 = black / rotten).

\section{Dry matter content}

The variation in dry matter content between unwashed and washed mushrooms was found to be significant. At the $3^{\text {rd }}$ day of storage, the highest dry matter content $(18.75 \%)$ was observed in unwashed mushrooms and the lowest (13.47\%) in washed mushrooms (Table 4). Modified atmosphere packaging caused significant effects in influencing dry matter content of oyster mushroom during the entire period of investigation. At the $7^{\text {th }}$ day of storage, the maximum $(83.32 \%)$ and the minimum $(8.17 \%)$ dry matter contents were found in mushrooms kept unwrapped and those wrapped with unperforated plastic bags, respectively (Table 5). The combined effects of washing and postharvest treatments were significant during of storage (Table 6). 


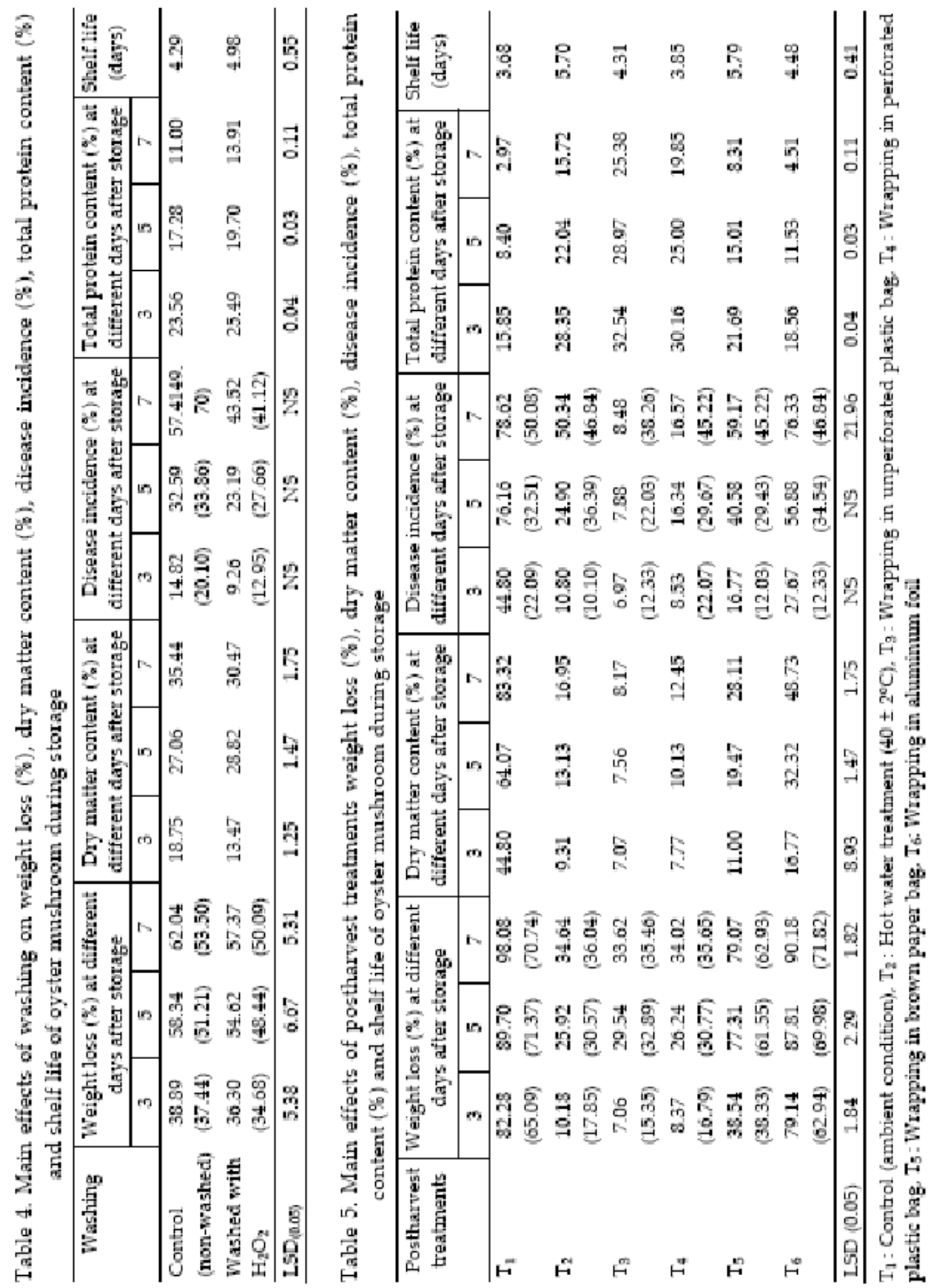




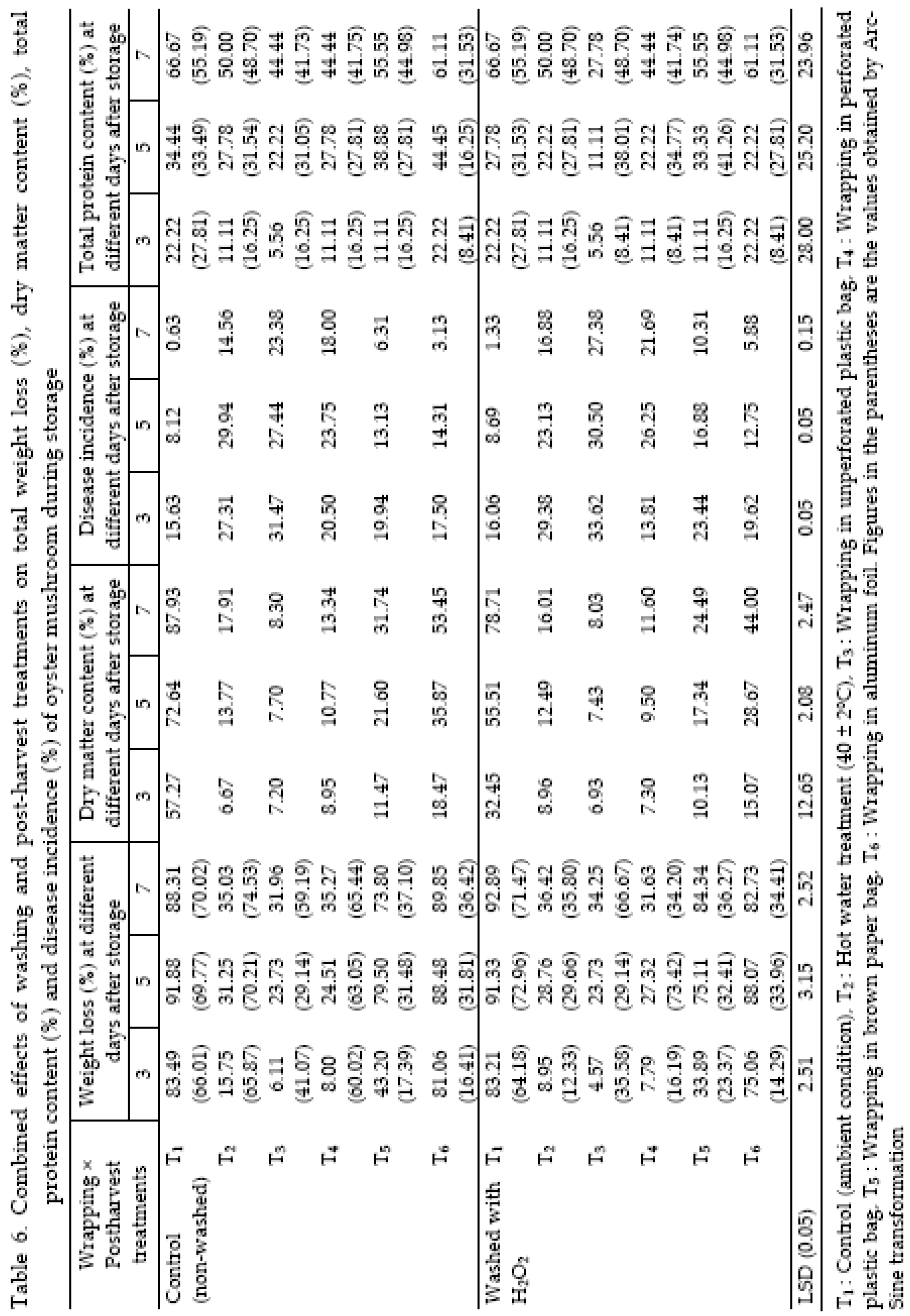




\section{Total protein content}

Protein content of mushrooms decreased gradually with storage duration. It decreased from 25.49 to $13.91 \%$ and 23.56 to $11.00 \%$ in the unwashed and washed mushrooms at the $3^{\text {rd }}$ and $7^{\text {th }}$ days of storage, respectively (Table 4). Modified atmosphere packaging exerted significant effects in influencing protein content of oyster mushroom. At the early part of storage, protein content was the highest $(32.54 \%)$ in mushrooms held in unperforated plastic bag and the lowest $(15.85 \%)$ was found in mushrooms held unwrapped. Protein contents dramatically declined in untreated mushrooms (15.85 to $2.97 \%$ from $3^{\text {rd }}$ to the $7^{\text {th }}$ day of storage, respectively). The rates of decrease in total protein contents were significantly slower in those mushrooms stored in plastic bags without perforation $(25.38 \%)$ and with perforations $(19.85 \%)$ at the $7^{\text {th }}$ day of storage (Table 5). In case of the combined effects of washing and different modified atmosphere packaging, significant variation was observed in relation to total protein content (Table 6).

\section{Disease incidence}

The disease level progressed with the duration of storage of oyster mushrooms. No significant variation in disease incidence was observed between unwashed and washed mushrooms under different postharvest treatments on different dates of counting. However, the washed mushrooms had lesser disease as compared to unwashed mushrooms (Table 4). Non-significant variation was also found in respect of postharvest storage treatments to influence disease incidence except at the $7^{\text {th }}$ day of storage. Mushrooms held in unperforated plastic bags maintained lower levels of infection during the entire period of investigation (Table 5).

\section{Shelf life}

Washing resulted in significant extension of shelf life of oyster mushroom. The shelf lives of the washed and unwashed mushrooms were 4.98 and 4.29 days, respectively. The effects of modified atmosphere packaging were also significant in extending shelf life of mushroom (Table 4). The shortest (3.68 days) and the longest (5.79 days) shelf lives were observed in mushrooms kept unwrapped and those wrapped in unperforated plastic bag, respectively (Table 5). The combined effects of washing and postharvest treatments were significant in relation to shelf life extension. The longest shelf life (6.2 days) was found in mushrooms that were washed and sealed in unperforated plastic bag (Fig. 1).

In conclusion, the shelf life of oyster mushroom would significantly be extended using modified atmosphere packaging, especially using unperforated plastic bags. This packaging also reduced the rates of protein degradation of mushroom after harvest. 


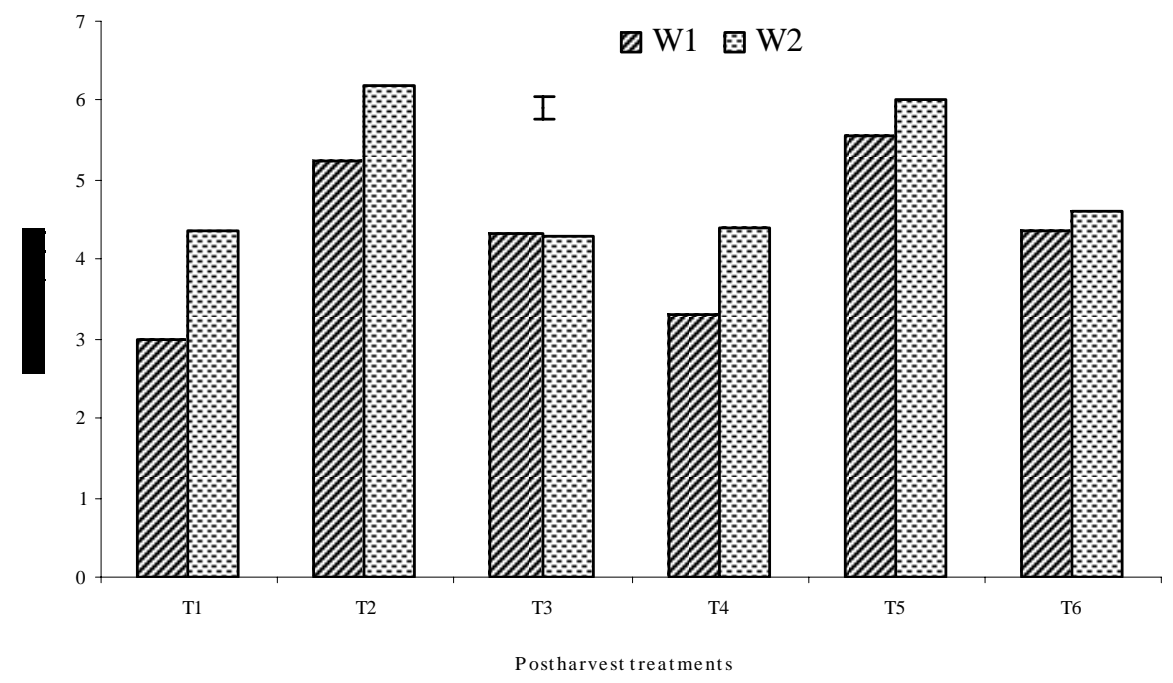

Fig. 1. The combined effects of different postharvest treatments and washing on changes of shelf life of oyster mushroom. Vertical bars indicate LSD at 5\% level of significance. W1 = Control (non-washed), $\mathrm{W}_{2}=$ Washed with $\mathrm{H}_{2} \mathrm{O}_{2}, \mathrm{~T}_{1}$ : Control (ambient condition), $\mathrm{T}_{2}$ : Hot water treatment $\left(40 \pm 2^{\circ} \mathrm{C}\right), \mathrm{T}_{3}$ : Wrapping in unperforated plastic bag, $\mathrm{T}_{4}$ : Wrapping in perforated plastic bag, $\mathrm{T}_{5}$ : Wrapping in brown paper bag, $\mathrm{T}_{6}$ : Wrapping in aluminum foil.

\section{REFERENCES}

AOAC (Association of Official Analytical Chemists). 1980. Official Methods of Analysis (13 ${ }^{\text {th }}$ Edn.), Washington, DC., USA.

Choi, M. H. and Kim, G. H. 2003. Quality changes in Pleurotus ostereatus during modified atmosphere storage as affected by temperatures and packaging material. Acta Hort., 628(1): 357-362.

Guthrie, B. D. and Beelman, R. B. 1989. Control of bacterial deterioration in fresh washed mushrooms. J. Mushroom. Sci., 689-700.

Gomez, K. A. and Gomez, A. A. 1984. Statistical Procedures for Agricultural Research. John Wiley and Sons Inc., New York.

Gothandapani, L., Parvathi, K. and Kennedy, Z. J. 1997. Evaluation of different methods of drying on the quality of oyster mushroom (Pleurotus sp). Dry Technol., 15(6/8): 1995-2004.

Jayathunge, L. and Illeperuma, C. 2001. Extension of postharvest life of oyster mushroom under ambient conditions by modified atmosphere packaging. J. Trop. Agril. Res., 13: 78-89.

Jayathunge, L. and Illeperuma, C. 2005. Extension of postharvest life of oyster mushroom by modified atmosphere packaging technique. J. Food. Sci., 70 (9): E573-E578.

Pathak, V. N., Yadav, N. and Gaur, M. 1997. Mushroom production and processing. Agrobios (India), Jodhpur, New Delhi 342, New Delhi.

Rajarathnam, S., Bano, Z. and Patwardhan, M. V. 1983. Post harvest physiology and storage of the white Oyster mushroom (Pleurotus flavellatus). J. Food Sci. Technol., 18(2): 153-162.

YounMoon, P., Sewon, P., Saejin, H. and Jiteun, H. 2004. Evaluation of storability and shelf life of oyster mushroom under simulated shipment and marketing environments. J. Hort. Sci. Korea, 45(1): 9-15. 